\title{
In Vitro Virucidal Effect of Povidone-Iodine Against SARS-CoV-2
}

\author{
Kyeong Ryeol Shin ${ }^{1+}$, Kyunghee Kwak $^{2+}$, Chunguang Cui ${ }^{1}$, Joon-Yong Bae ${ }^{1}$, Woosung Hong ${ }^{2 *}$, Man-Seong Park ${ }^{1 *}$ \\ ${ }^{1}$ Department of Microbiology, Institute for Viral Diseases, College of Medicine, Korea University, Seoul 02841, Republic of Korea \\ ${ }^{2}$ Mundipharma Korea Ltd. Medical Department, Seoul 04637, Republic of Korea \\ +These authors equally contributed to this work.
}

\author{
Corresponding \\ Woosung Hong, Medical Director, \\ Mundipharma Korea Ltd. Medical \\ Department, Seoul 04637, Republic of \\ Korea \\ Man-Seong Park, Professor, Department \\ of Microbiology, Korea University \\ College of Medicine, Seoul 02841, \\ Republic of Korea \\ Phone : +82-2-6450-9345 \\ Fax : +82-2-568-5634 \\ E-mail : WooSung.Hong@mundipharma.co.kr; \\ manseong.park@gmail.com
}

Received : August 18, 2020

Revised : September 20, 2020

Accepted : September 22, 2020 to this article was reported.

Copyright (C) 2020 Journal of Bacteriology and Virology

(C) This is an Open Access article distributed under the terms of the Creative Commons Attribution Non-Commercial License

(http://creativecommons.org/ license/by-nc/3.0/).
As of September 2020, SARS-CoV-2 has infected over 30 million people worldwide, and the death toll has now risen to 950,000. Given that Povidone-iodine (PVP-I) had consistently been showing the virucidal efficacy against various types of viruses, such as SARS-CoV, MERS-CoV, and Ebola, we conducted this study to figure out the virucidal effect against SARS-CoV-2 by using a viral plaque assay. We performed Kill-Time assays to assess the viral inactivation of SARS-CoV-2 contaminants after the application of the PVP-I product (Betadine ${ }^{\circledR}$ Throat Spray, PVP-I $0.45 \%)$. This test consisted of clean and dirty conditions and was designed to check the viral titers at a contact time of 60 seconds, which were evaluated by plaque-reduction rates in Vero cells. This PVP-I product fully achieved $\geq 4 \log _{10}$ reductions in viral titers under both clean and dirty conditions. This level of reduction, $\geq 4 \log _{10}(99.99 \%)$, in viral titers presented to be effective in terms of virucidal efficacy, according to the European standards, EN14476. This study revealed the virucidal efficacy of Betadine ${ }^{\circledR}$ Throat Spray against SARS-CoV-2 virus. Given that the convenience and availability of this product, we think that it may contribute to inhibit viral infection and transmissibility as an active type of personal protective equipment (PPE) by managing the hygiene of patients and medical professionals.

Key Words: COVID-19, SARS-CoV-2, Plaque, Povidone-iodine, Virucidal effect

\section{INTRODUCTION}

2019년 말 중국 우한 지역에서 촉발된 신종코로나바이러스(novel coronavirus, SARS-CoV-2) 감염의 전세계적인 확산으로 모든 대륙의 나라들이 확산 방지에 사력을 다하고 있다. 대유 행이 시작되고 2020년 9월 현재 코로나바이러스감염증-19에 감염된 사람들은 총 3,000 만명 이상이며 95만명 이상이 사망한 것으로 보고되었다 (1).

SARS-CoV-2 바이러스의 존재가 인지된 지 몇 개월에 불과하여 아직 코로나바이러스감염 증-19에 대해 입증된 치료 및 예방 방법이 제시되지 못하고 있다. 현재 약물 재창출 또는 신약 기반의 항바이러스제들이 임상중이나, 해당 약제들이 정식 허가를 통해 시판에 이르 기 까지는 아직 요원한 상황으로 판단된다 (2). 그러므로, 코로나바이러스감염증-19에 대 한 적절한 치료제나 백신이 존재하지 않는 공백 상황에서 감염 예방 및 관리를 목적으로 활 용 가능한 약제의 효용성을 확인하는 것은 매우 중요한 일이라 할 수 있다.

본 논문에서는 포비돈 요오드가 코로나바이러스감염증-19을 유발하는 바이러스를 제거하는 능 력을 in vitro 실험을 통해 확인하였다. 이를 통해, 의료진과 일반 대중에게 쉽게 일상 생활에서 적 용 가능한 실용적 대안으로 포비돈 요오드(PVP-I, Betadine $\left.{ }^{\circledR}\right)$ 의 활용 가능성을 논의하고자 한다. 
포비돈 요오드의 항바이러스 기전

포비돈 요오드는 전자전달계(electron transport chain or respiratory chain)에 관여하는 cytosolic enzyme과 세포막의 뉴클레오티 드, 지방산 및 아미노산을 산화시켜 변성을 유도하고 병원균의 DNA와 RNA를 불활성화 한다 (3). 살균 과정의 상세 기전은 명확히 밝 혀진 바 없지만 다음과 같이 설명되고 있다 (4). 포비돈 요오드의 살균 효과는 주로 요오드 원소(element iodine, $I_{2}$ )와 하이포아요오 드산(hypoiodous acid, HIO)에 의한 것으로 알려져 있는데, 포비돈 또한 단백질내 티로신(tyrosine)의 페놀군(phenoilc group)에 결합하여 반응하거나 병원균 세포벽 단백질의 카복실산(carboxylic acid)에 결합하여 반응하기도 한다 (5). 그러나, 요오드는 구조적 으로 매우 불안정하여, 포비돈이 캐리어 역할을 하면서 요오드가 수용성을 유지할 수 있도록 돕는 보조 기능의 역할도 수행하는 것으로 알려져 있다.

Beukelman 등이 실시한 세포독성 연구에 의하면, 포비돈 요오드의 살균 효과는 세포가 영향을 받기 전에 나타나는 것으로 알려져 있다. 상기 연구에서, 포비돈 요오드가 광범위한 살균 효과를 보이는 동시에 병원균과 숙주의 상호작용에 의해 유발되는 염증을 저해하는 작용 도 있음이 보고되어 포비돈 요오드의 임상적 가능성을 시사하였다 (6).

\section{포비돈 요오드의 광범위 살균 효과}

포비돈 요오드의 광범위한 살균 효과는 박테리아, 바이러스, 원충 및 곰팡이에 이르는 것으로 알려져 있다 (7). 그 중에서도 바이러스는 볼거리, 단순헤르페스, 풍진, 홍역, 인플루엔자, 사람면역결핍바이러스 및 코로나바이러스와 같은 외피보유바이러스(enveloped virus) 와 아데노-, 로타-, 폴리오-, 콕사키- 및 리노바이러스(rhinovirus) 같은 외피비보유바이러스(non-enveloped virus) 등 다양한 바이러스 에 항바이러스 효능을 보이는 것으로 보고되었다 (8-15).

특히, 포비돈 요오드는 전 세계적으로 급성호흡기 감염을 확산시킨 중증급성호흡기증후군 코로나바이러스(SARS-CoV)와 중동호흡기증 후군 코로나바이러스(MERS-CoV)의 감염능을 비활성화(viral inactivation)하는 효능이 보고되었다 $(16,17)$. 이런 연구결과를 바탕으 로 코로나바이러스감염증-19의 원인 바이러스인 SARS-CoV-2에 대한 항바이러스 효능을 분석한 결과, 대조군 대비 $4 \log _{10}$ 이상 바이 러스를 제거하는 효능이 확인되었다 $(18,19)$. 이와 같이 포비돈 요오드는 급성 호흡기 감염을 유발하는 인플루엔자바이러스, 코로나바 이러스 등 다양한 바이러스에 항바이러스 효능을 갖고 있음이 확인되었다 (Table 1) (20-22).

Table 1. Virucidal activity of povidone-iodine products

\begin{tabular}{|c|c|c|c|c|}
\hline Virus & $\begin{array}{l}\text { Povidone-iodine } \\
\text { concentration (\%) }\end{array}$ & $\begin{array}{l}\text { Duration (sec) } \\
\text { Condition }\end{array}$ & Log10 reduction factor & Reference \\
\hline SARS-CoV & 0.23 & $\begin{array}{c}15 \\
\text { Clean \& Dirty }\end{array}$ & $>4 \log$ & Eggers et al., 2018 \\
\hline \multirow[t]{2}{*}{ SARS-CoV-2 } & 0.45 to 10 & $\begin{array}{l}30 \\
\text { Clean }\end{array}$ & $>4 \log$ & Anderson et al., 2020 \\
\hline & $0.5,1$ & $\begin{array}{c}15,30,60 \\
\text { Clean \& Dirty }\end{array}$ & $\begin{array}{l}>5 \log (4 \log \text { at } 0.5 \% \\
15 \mathrm{sec})\end{array}$ & Hassandarvish et al., 2020 \\
\hline \multirow[t]{2}{*}{ MERS-CoV } & 0.23 & $\begin{array}{c}15 \\
\text { Clean \& Dirty }\end{array}$ & $>4 \log$ & Eggers et al., 2018 \\
\hline & $1,4,7.5$ & $\begin{array}{c}15 \\
\text { Clean \& Dirty }\end{array}$ & $>4 \log$ & $\begin{array}{l}\text { Eggers et al., } 2015 \text { (Infec } \\
\text { Dis Ther) }\end{array}$ \\
\hline \multirow{2}{*}{$\begin{array}{l}\text { MVA } \\
\text { (Modified vaccinia virus } \\
\text { Ankara) }\end{array}$} & 0.032 to 10 & $\begin{array}{l}15,30,60 \\
\text { Clean \& Dirty }\end{array}$ & $>4 \log$ (above 0.4) & $\begin{array}{l}\text { Eggers et al., } 2015 \text { (BMC } \\
\text { Infec Dis) }\end{array}$ \\
\hline & 0.001 to 7.5 & $\begin{array}{c}15,30,60 \\
\text { Clean \& Dirty }\end{array}$ & $>4 \log$ (above 0.1) & $\begin{array}{l}\text { Eggers et al., } 2015 \text { (Infec } \\
\text { Dis Ther) }\end{array}$ \\
\hline $\begin{array}{l}\text { Non-enveloped human } \\
\text { rotavirus strain Wa }\end{array}$ & $0.0023,0.023,0.23$ & $\begin{array}{l}\text { 15, 30. } 60,120 \\
\text { Clean }\end{array}$ & $>4 \log$ (only at 0.23 ) & Eggers et al., 2018 \\
\hline $\begin{array}{l}\text { Influenza virus A } \\
\text { subtype H1N1 }\end{array}$ & $0.0023,0.023,0.23$ & $\begin{array}{c}15,30 \\
\text { Clean \& Dirty }\end{array}$ & $\begin{array}{c}>4 \log (\text { except at } \\
0.0023)\end{array}$ & Eggers et al., 2018 \\
\hline
\end{tabular}




\title{
MATERIALS AND METHODS
}

\author{
바이러스 사멸 판정
}

포비돈 요오드 인후 스프레이 제품으로 코로나바이러스감염증-19 유발 바이러스에 대한 in vitro 효능평가 시험을 진행하였다. SARS-CoV-2 바이러스에 대한 포비돈 요오드 제품의 바이러스 사멸 효과(virucidal effect)는 이전 중증급성호흡기증후군 코로나바이러 스와 중동호흡기증후군 코로나바이러스의 효능 테스트에 사용된 EN14476 소독제 테스트 방법을 활용하였으며, 바이러스 사멸 효과를 시간에 따라 평가하는 방식을 따랐다. 유럽 기준에 따라 바이러스 역가(viral titer)가 대조군 대비 $4 \log _{10}$ 이상 감소하면 시험군 제품이 바이러스를 사멸하는 효능이 있다고 판단하였다 (20).

바이러스 배양

SARS-CoV-2 바이러스(nCoV/Korea/KUMC-01/2020)는 Vero 세포에 증식시켰으며, Vero 세포는 5\% FBS를 포함한 DMEM 배지에 서 배양되었다. 시험분석용 바이러스를 준비하기 위해, 세포 단층에 바이러스를 감염시킨 후 $37^{\circ} \mathrm{C}$ 의 $5 \% \mathrm{CO}_{2}$ 배양기에서 3 일간 배양하 였다. 배양 후 상층액을 채취하여 원심분리로 여과한 후 -80에 보관하였다.

포비돈 요오드의 세포독성 분석

세포독성 시험은 포비돈 요오드 인후 스프레이 제품을 10배씩 단계 희석한 후 Vero 세포에 처리하여 진행하였다. 포비돈 요오드가 처리 된 Vero 세포를 $37^{\circ} \mathrm{C}$ 에서 3 일간 배양한 후 세포병변효과를 관찰하여, 세포병변이 관찰되지 않는 가장 높은 희석배수를 확인하여 세포독 성 여부를 분석하였다.

포비돈 요오드의 바이러스 제거능력(Kill Time) 분석

포비돈 요오드의 바이러스 사멸능력을 평가하기 위해, 포비돈 요오드 인후 스프레이 제품을 바이러스 용액과 $20^{\circ} \mathrm{C}$ 에서 60 초간 혼합하였 다. 좀 더 상세히 설명하면 다음과 같다. 포비돈 요오드 인후 스프레이 제품 $800 \mu \mathrm{L}$ 을 0.3g/L BSA가 들어 있는 $200 \mu \mathrm{l} \mathrm{PBS}$ 와 혼합 (Clean 조건)시키거나 또는 $3 \mathrm{~g} / \mathrm{L} \mathrm{BSA}$ 및 $3 \mathrm{ml} / \mathrm{L}$ sheep erythrocytes가 들어 있는 $200 \mu \mathrm{l} \mathrm{PBS}$ 에 혼합(Dirty 조건)한다. 혼합 후, 반응 용액 $100 \mu \mathrm{L}$ 에 $5 \times 10^{7} \mathrm{PFU} / \mathrm{ml}$ 이 들어 있는 바이러스 용액 $100 \mu \mathrm{L}$ 를 넣고 60초간 반응을 시킨다. 중화반응 후 $200 \mu \mathrm{l}$ 를 채취하여 바이러 스 정량을 위해 10 배씩 단계 희석을 진행한다. 희석한 샘플을 Vero cell에 $100 \mu$ 씩 넣고 1 시간 동안 $37^{\circ} \mathrm{C}$ 배양기에서 감염시킨다. 1 시 간 동안 감염시킨 후 PBS로 세포를 세척하고 overlay media를 첨가하여 plaque assay를 진행한다. $37^{\circ} \mathrm{C}, 5 \% \mathrm{CO}_{2}$ 배양기에 $3-4$ 일간 배양 후 plaque를 확인하여 바이러스 역가를 측정한다. 대조군으로는 PVP-I 제품 대신 $800 \mu \mathrm{L} \mathrm{PBS}$ 를 사용하였다 (Fig. 1).

\section{RESULTS}

본 실험은 Vero 세포에 대한 포비돈 요오드 제품의 세포독성을 먼저 분석한 후 바이러스의 제거능력을 평가하였다. 포비돈 요오드 인후 스프레이 제품은 1,000 배 이상 희석될 경우, Vero 세포에서 독성은 관찰되지 않았다. 포비돈 요오드 제품의 바이러스 사멸 효과를 확인 하기 위해 SARS-CoV-2 바이러스를 포비돈 요오드 제품에 60초 동안 노출하였다. 이 시험을 통해 도출된 바이러스 제거 성능이 포비돈 요오드 자체 성능에 의한 것이 아니라 포비돈 요오드로 인해 유도된 세포독성으로 바이러스 증식이 억제되어 나타난 오류인지 확인하기 위해 중화시험을 수행하였다. 그 결과, Fig. 2에 기술된 것처럼 포비돈 요오드의 바이러스 사멸효과는 세포독성에 의한 것이 아니라 그 자 체 물질의 성능에 의한 것으로 확인되었다. Kill Time 실험 결과, clean 조건에서 포비돈 요오드 인후 스프레이 제품은 바이러스 역가를 5 $\log _{10}$ 이상 감소시켰다 (Fig. 3). 또한 dirty 조건에서도 바이러스 역가가 $4 \log _{10}$ 이상 감소되어 바이러스를 $99.99 \%$ 이상 사멸시키는 효과를 보여주었다 (Fig. 3, Fig. 4). 


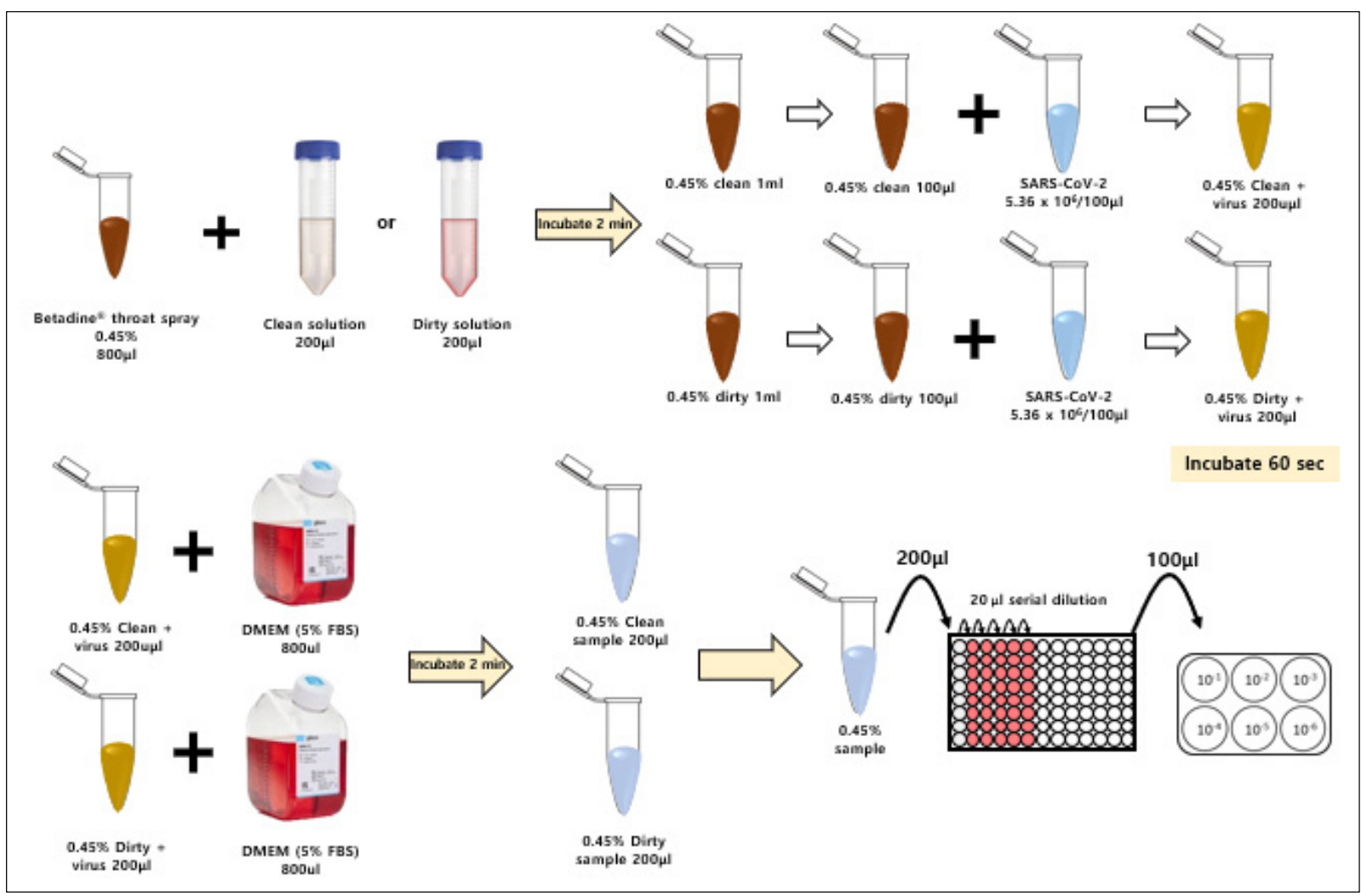

Fig. 1. Virucidal assay to assess in vitro virucidal effect of povidone-iodine product.

\begin{tabular}{|c|c|c|c|}
\hline \multirow{2}{*}{ Dilution } & \multicolumn{3}{|c|}{ SARS-CoV-2 } \\
\cline { 2 - 4 } & Clean condition & Dirty condition & PBS \\
\hline Control & & ++++ & ++++ \\
\hline $10^{-1}$ & ++++ & ++++ & ++++ \\
\hline $10^{-2}$ & ++++ & ++++ & ++++ \\
\hline $10^{-3}$ & ++++ & ++++ & \\
\hline
\end{tabular}

Fig. 2. Neutralization assay under clean \& dirty condition (Control: virus only, +: virus recovered, -: no virus recovered).

\section{DISCUSSION}

코로나바이러스감염증- 19 의 대유행은 환자의 정확한 조기 진단 및 효율적인 위생 관리 수칙과 같은 예방적 조치가 전략적으로 적절히 이 루어졌을 때, 비로소 전파 유행 위험을 감소시킬 수 있다. 또한, 병원 내에서는 단순한 보호 장구와 같은 수동적 위생관리를 넘어서 환자 의 치료 및 의료진의 보호 목적을 위한 적극적인 위생관리 방법이 마련되어야 한다.

최근에는 이러한 목적으로 개인보호장구(personal protective equipment, PPE)들의 활용 방법과 시술 지침이 소개되고 있는데, 특히 광범위한 살균 효과를 배경으로 포비돈 요오드를 비강 및 구강의 수술 전후 감염관리에 활용하도록 권유하고 있다. 특정 농도의 포비돈 요오드는 비강 및 구강에서 안전성이 오랜 기간 입증되어 이를 적극적으로 활용할 수 있는 배경은 이미 마련되었다고 판단할 수 있다 (23). 인플루엔자와 같은 호흡기 병원체는 작은 입자 $(\leq 5 \mu \mathrm{m})$ 크기로 인해 환자가 숨을 쉬고 재채기 및 기침을 하면서 공기를 매개로 확 산되지만, 호흡기세포융합바이러스(respiratory syncytial virus)나 중증급성호흡기증후군 코로나바이러스(SARS-CoV), 중동호흡기증 후군 코로나바이러스(MERS-CoV) 및 코로나바이러스감염증-19 (SARS-CoV-2) 등은 주로 비말이 사람의 눈, 코 및 입 등에 묻어 전파되 는 것으로 알려져 있다 $(24,25)$. 이러한 전파 양상을 고려할 때, 손씻기 뿐만 아니라 포비돈 요오드를 활용한 구강, 비강 및 인후부의 적 극적 위생 관리는 코로나바이러스감염증-19에 대한 감염 관리에 큰 도움이 될 수 있을 것으로 판단된다. 
(A)

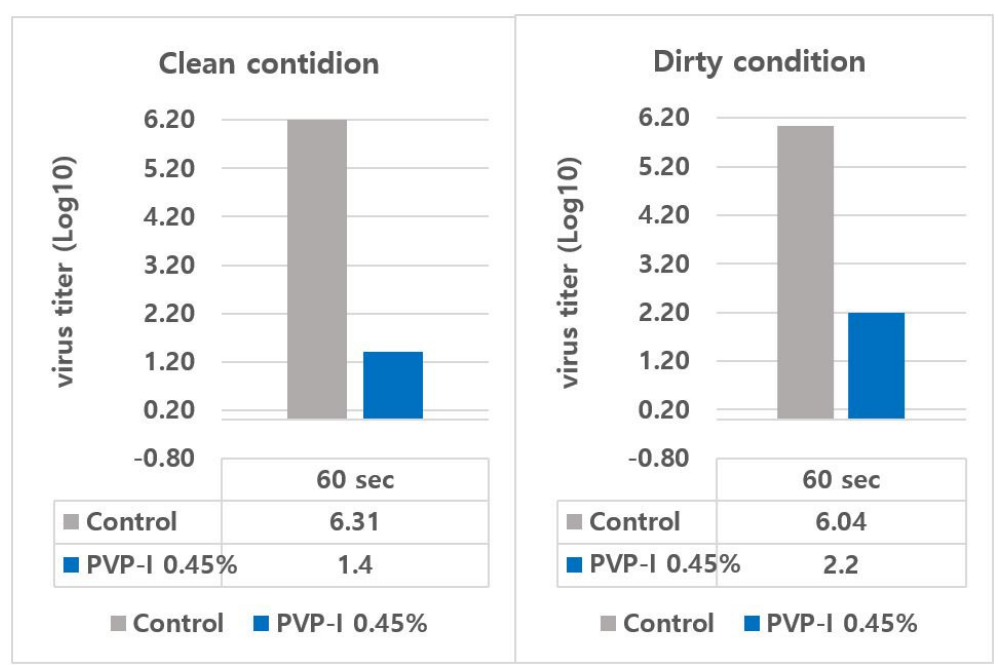

(B)

\begin{tabular}{|c|c|c|}
\hline \multicolumn{3}{|c|}{ The virus removal rate of the test group (PVP-I, 0.45\%) compared to the control group } \\
\hline Condition & Clean condition & Dirty condition \\
\hline Percentage (\%) & 99.999 & 99.99 \\
\hline
\end{tabular}

Fig. 3. In vitro virucidal effect of povidone-iodine against SARS-CoV-2. (A) The virus titers under clean and dirty conditions $\left(\log _{10}\right)(B)$ The comparison of viral titers under clean \& dirty conditions (\%).

Kirk-Bayley 등은 포비돈 요오드의 비강 스프레이 및 구강 세척 방법을 환자와 의료진 모두에게 적용하도록 권유하였으며, 이를 활용하는 방법을 구체적인 가이드를 통해 제시한 바 있다 (26). Mady 등도 환자와 의사 모두를 대상으로 유사한 전략의 필요성을 주장하였으며 비 강 세척과 구강 및 인두부의 세정을 강조하였다 (27). 포비돈 요오드를 활용한 가글의 유용성에 대해서는 일본 임상 호흡기 감염 가이드 라인을 통해서도 구체적으로 확인할 수 있다 (28).

미국 텍사스 의과대학의 Ather 등은 치과 진료 중 포비돈 요오드를 활용한 예방책을 통하여 환자 진료 중 적극적으로 코로나바이러스감 염증-19에 대한 감염 관리를 할 수 있도록 유도하고 있다. 시술 전 $0.2 \%$ 포비돈 요오드를 활용하여 환자의 구강을 세척하면 타액 내 SARS-CoV-2바이러스의 총량을 줄일 수 있다는 원리로 Kirk-Bayley 및 Mady 등의 연구 의도와 동일한 가설에 근거한 지침이다 (29). 또한, 안면부 성형 수술 및 두경부와 상기도 점막을 다루는 외과적 시술이 필요한 경우에도 예방적 중재를 목적으로 포비돈 요오드를 활 용한 처치를 권장한다 (30-32).

이와 같이, 다양한 기관의 의료진과 환자를 대상으로 감염 예방 및 관리 지침이 일관적으로 포비돈 요오드의 활용을 기술하고 있으며 이 사실은 그만큼 해당 약제가 광범위한 살균력을 갖고 있을 뿐 아니라 과거 SARS-CoV 바이러스 및 MERS-CoV 바이러스에 대한 실험 결 과가 코로나바이러스감염증-19에도 유사하게 나타날 것이라는 가설에 따른 것이다. 이러한 가설을 입증하기 위해, 최근 독일과 싱가포르 연구자들에 의해 in vitro 실험이 진행되었고, 일반적으로 구강 살균을 목적으로 사용되는 농도 $(0.5 \%, 1.0 \%, 1.5 \%)$ 의 포비돈 요오드 는 불과 15초 이내에 SARS-CoV-2 바이러스의 불활화를 이끌어 낸다는 것이 확인되었다 (33). 또한 말레이시아 연구자들이 수행한 가글 과 구강 세정용 포비돈 요오드 역시 15초 이내 $5 \log 10$ 이상의 감소를 보여주며 유사한 연구 결과가 도출되었다 (19).

본 연구는 국내에서 처음으로 이루어진 $0.45 \%$ 포비돈 요오드의 SARS-CoV-2 바이러스에 대한 효능평가로 반수세포감염량(TCID 50 )을 통해 결과를 확인했던 다른 연구들과 달리 플라크 정량법(plaque assay)을 도입하여 바이러스 사멸효과를 평가하였다. 플라크 정량법은 바이러스 감염 후 특징적인 플라크가 세포내에 생성되며, 감염성이 있는 하나의 바이러스 입자는 하나의 플라크를 형성한다는 이론하에 다양한 바이러스의 정량에 사용되고 있다 (34). 이 정량 방법을 이용하여 포비돈 요오드의 SARS-CoV-2 바이러스 사멸 효과를 확인하기 위한 테스트를 수회 반복하여도 큰 오차없이 사멸효과가 일관되게 관찰되었다 (35). 이러한 국내외 연구를 통해 도출된 과학적 근거를 바 탕으로 $0.45 \%$ 포비돈 요오드 인후 스프레이를 포함한 포비돈 요오드 관련 제품의 적절한 활용은 아직 백신과 치료제가 개발되지 않은 상황에서 코로나바이러스감염증-19 예방 및 관리에 큰 기여를 할 수 있을 것으로 사료된다. 

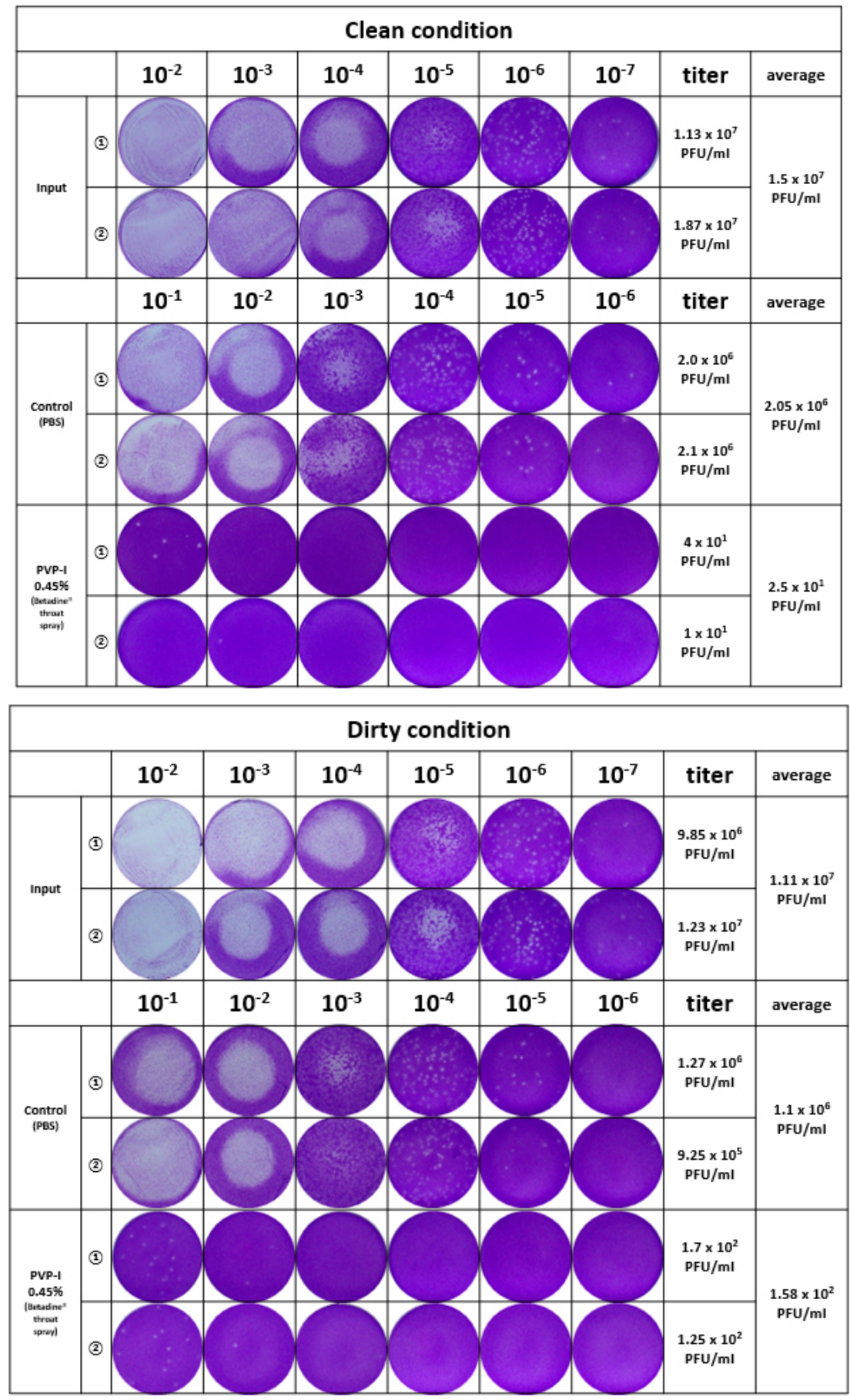

Fig. 4. The plaque assay for titration of SARS-CoV-2 virus from control and experimental groups.

\section{ACKNOWLEDGMENTS}

We would like to thank the researchers isolated the SARS-CoV-2 virus from clinical samples. 


\section{REFERENCES}

1) WHO. WHO Coronavirus Disease (COVID-19) Dashboard 2020 [cited 202223 June]. Globally, as of 3:50pm CEST, 22 June 2020, there have been 8,860,331 confirmed cases of COVID-19, including 465,740 deaths, reported to WHO.]. Available from: https://covid19.who.int/1.

2) Zhang J, Xie B, Hashimoto K. Current status of potential therapeutic candidates for the COVID-19 crisis. Brain Behav Immun 2020;87:59-73.

3) Kanagalingam J, Feliciano R, Hah JH, Labib H, Le TA, Lin JC. Practical use of povidone-iodine antiseptic in the maintenance of oral health and in the prevention and treatment of common oropharyngeal infections. Int J Clin Pract 2015:69:1247-56.

4) Bigliardi PL, Alsagoff SAL, El-Kafrawi HY, Pyon JK, Wa CTC, Villa MA. Povidone iodine in wound healing: A review of current concepts and practices. Int J Surg 2017:44:260-8.

5) Eugene S. Barabas HGB. Analytical Profiles of Drug Substances and Excipients. In: Brittain HG, editor. Povidone lodine. 251998. p. 341-462.

6) Beukelman CJ, van den Berg AJJ, Hoekstra MJ, Uhl R, Reimer K, Mueller S. Anti-inflammatory properties of a liposomal hydrogel with povidone-iodine (Repithel) for wound healing in vitro. Burns 2008:34:845-55.

7) Hierholzer G, Reimer K, Weissenbacher E. Topische Infektionstherapie und Prophylaxe. Aktueller Stellenwert von PVP-Jod. Stuttgart: Thieme; 1996.

8) Wood A, Payne D. The action of three antiseptics/disinfectants against enveloped and non-enveloped viruses. $\int$ Hosp Infect 1998;38:283-95.

9) Kawana R, Kitamura T, Nakagomi O, Matsumoto I, Arita M, Yoshihara N, et al. Inactivation of human viruses by povidone-iodine in comparison with other antiseptics. Dermatology 1997:195:29-35.

10) Wutzler P, Sauerbrei A, Klöcking R, Brögmann B, Reimer K. Virucidal activity and cytotoxicity of the liposomal formulation of povidone-iodine. Antiviral Res 2002:54:89-97.

11) Sauerbrei A, Sehr $K$, Eichhorn U, Reimer $K$, Wutzler $P$. Inactivation of human adenovirus genome by different groups of disinfectants. J Hosp Infect 2004;57:67-72.

12) Kariwa H, Fujii N, Takashima I. Inactivation of SARS coronavirus by means of povidone-iodine, physical conditions, and chemical reagents. Jpn J Vet Res 2004:52:105-12.

13) Ito $H$, Ito $T$, Hikida $M$, Yashiro J, Otsuka $A$, Kida $H$, et al. Outbreak of highly pathogenic avian influenza in Japan and anti-influenza virus activity of povidone-iodine products. Dermatology 2006:212:115-8.

14) Ito $H$, Hikida $M$, Yashiro J, Kida $H$, Ito $T$. Virucidal efficacy of povidone-iodine products against swine influenza viruses. Jpn J Chemother 2009;57:508-10.

15) Sauerbrei A, Wutzler P. Virucidal efficacy of povidone-iodine-containing disinfectants. Lett Appl Microbiol 2010;51:158-63.

16) Eggers M, Eickmann M, Zorm J. Rapid and Effective Virucidal Activity of Povidone-lodine Products Against Middle East Respiratory Syndrome Coronavirus (MERS-CoV) and Modified Vaccinia Virus Ankara (MVA). Infect Dis Ther 2015:4:491-501.

17) Kariwa H, Fuji N, Takashima I. Inactivation of SARS coronavirus by means of povidone-iodine, physical conditions and chemical reagents. Dermatology 2006:212:119-23. 
18) Anderson DE, Sivalingam V, Kang AEZ, Ananthanarayanan A, Arumugam $H$, Jenkins TM, et al. Povidone-iodine demonstrates rapid in-vitro virucidal activity against SARS-CoV-2, the virus causing COVID-19 disease. Infect Dis Ther 2020;9:669-75.

19) Hassandarvish $P$, Tiong $V$, Sazaly $A B$, Mohamed NA, Arumugam $H$, Ananthanarayanan $A$, et al. Povidone iodine gargle and mouthwash. Br Dent J 2020;228:900.

20) Eggers $M$, Koburger-Janssen $T$, Eickmann M, Zorn J. In vitro bactericidal and virucidal efficacy of Povidone-lodine gargle/mouthwash against respiratory and oral tract pathogens. Infect Dis Ther 2018;7:249-59.

21) Eggers M, Eickmann M, Kowalski K, Zorn J, Reimer K. Povidone-iodine hand wash and hand rub products demonstrated excellent in vitro virucidal efficacy against Ebola virus and modified vaccinia virus Ankara, the new European test virus for enveloped viruses. BMC infect Dis 2015;15:375.

22) Eggers M, Eickmann M, Zorn J. Rapid and effective virucidal activity of povidone-iodine products against Middle East respiratory syndrome coronavirus (MERS-CoV) and modified vaccinia virus ankara (MVA). Infect Dis Ther 2015;4:491-501.

23) Vukkadala N, Qian ZJ, Holsinger FC, Patel ZM, Rosenthal E. COVID-19 and the otolaryngologist: preliminary evidencebased review. Laryngoscope 2020

24) Gralton J, Tovey ER, McLaws ML, Rawlinson WD. Respiratory virus RNA is detectable in airborne and droplet particles. J Med Viro/2013:85:2151-9.

25) Organization WH. Consensus document on the epidemiology of severe acute respiratory syndrome (SARS). World Health Organization, 2003.

26) Kirk-Bayley J, Challacombe S, Sunkaraneni VS, Combes J. The Use of Povidone lodine Nasal Spray and Mouthwash During the Current COVID-19 Pandemic May Protect Healthcare Workers and Reduce Cross Infection. 2020:SSRN Electronic J 3563092.

27) Mady LJ, Kubik MW, Baddour K, Snyderman CH, Rowan NR. Consideration of povidone-iodine as a public health intervention for COVID-19: Utilization as "Personal Protective Equipment" for frontline providers exposed in high-risk head and neck and skull base oncology care. Oral Onco/2020;105:104724

28) The committee for The Japanese Respiratory Society guidelines in management of respiratory infections. Prevention of hospital-acquired pneumonia (strategies for prevention of hospital-acquired infections). Respirology 2004;9:S48-S50.

29) Ather A, Patel B, Ruparel NB, Diogenes A, Hargreaves KM. Coronavirus disease 19 (COVID-19): implications for clinical dental care. J Endod 2020;46:584-95.

30) Bali RK, Chaudhry K. Maxillofacial surgery and COVID-19, The Pandemic!!. J Maxillofac Oral Surg 2020;19:159-61.

31) Parhar HS, Tasche K, Brody RM, Weinstein GS, O’Malley Jr BW, Shanti RM, et al. Topical preparations to reduce SARSCoV-2 aerosolization in head and neck mucosal surgery. Head Neck 2020;42:1268-72.

32) Pattanshetty S, Narayana A, Radhakrishnan R. Povidone-iodine gargle as a prophylactic intervention to interrupt the transmission of SARS-CoV-2. Oral Dis 2020;10.1111.

33) Bidra AS, Pelletier JS, Westover JB, Frank S, Brown SM, Tessema B. Rapid In-Vitro Inactivation of Severe Acute Respiratory Syndrome Coronavirus 2 (SARS-CoV-2) Using Povidone-lodine Oral Antiseptic Rinse. J Prosthodont 2020;29:529-33.

34) Darling AJ, Boose JA, Spaltro J. Virus assay methods: accuracy and validation. Biologicals 1998;26:105-10

35) LaBarre DD, Lowy RJ. Improvements in methods for calculating virus titer estimates from TCID50 and plaque assays. J Virol Methods 2001:96:107-26. 